\title{
Pengaruh Laba Akuntansi, Arus Kas Operasi, Return On Equity, Dan Return On Asset Terhadap Return Saham
}

\author{
Maria Verensiana Uhus \\ e-mail: anneyuhus12@yahoo.com \\ Rita Indah Mustikowati \\ Supami Wahyu Setiyowati \\ Program Studi Akuntansi, Fakultas Ekonomika dan Bisnis, Universitas Kanjuruhan Malang
}

\begin{abstract}
Abstrak
Tujuan penelitian ini yaitu untuk menguji pengaruh $\mathrm{LAK}, \mathrm{AKO}, \mathrm{ROE}$, dan $R O A$, terhadap $R S$ secara simultan dan secara parsial. Teknik yang digunakan peneliti dalam pengambilan sampel adalah menggunakan Purposive Sampling pada perusahaan LQ 45 yang terdaftar di Bursa Efek Indonesia (BEI) karena dalam pengambilan sampel menggunakan kriteria tertentu. Penelitian dilakukan dalam kurun waktu 2016-2018. Metode analisis menggunakan analisis regresi linear berganda yaitu program SPSS 22. Hasil penelitian menunjukan secara simultan LAK, AKO, ROE, dan $R O A$ berpengaruh terhadap $R S$ dan secara parsial LAK dan AKO memiliki pengaruh terhadap $R S$, sedangkan ROE dan ROA tidak memiliki prngaruh terhadap $R S$.
\end{abstract}

Kata Kunci: laba akuntansi, arus kas operasi, return on equity, return on asset, dan Return saham.

\section{Abstract}

The purpose of this study was to examine the effect of $S A R, A K O, R O E$, and ROA on the hospital simultaneously and partially. The technique used by researchers in sampling is using purposive sampling at LQ 45 companies listed on the Indonesia Stock Exchange (BEI) because the sampling uses certain criteria. The research was conducted in the period 2016-2018. The method of analysis used multiple linear regression analysis, namely the SPSS 22 program. The results showed that simultaneously SAR, AKO, ROE, and ROA had an effect on hospitals and partially LAK and AKO had an effect on hospitals, while ROE and ROA had no effect on hospitals.

Keywords accounting profit, operating cash flow, return on equity, return on assets, and stock returns. 


\section{Maria Verensiana Uhus, Pengaruh Laba Akuntansi, Arus Kas Operasi, Return On Equity, Dan Return}

On Asset Terhadap Return Saham

\section{PENDAHULUAN}

Perkembangan ekonomi di era globalisasi saat ini mengalami perubahan yang cukup signifikan, sehingga dunia usahapun ikut berkembang dan semakin banyak pula perusahaan yang muncul terutama perusahaan yang sudah go publik. Hal tersebut menyebabkan setiap perusahaan mempunyai daya saing yang cukup tinggi untuk mencapai laba yang semaksimal mungkin, sehingga setiap perusahaan mempunyai upaya untuk menambahkan dana melalui berinvestasi. Keadaan yang seperti ini menuntut kebutuhan dana yang cukup bagi setiap perusahaan untuk bertahan dan bersaing di dunia usaha.

Fenomena yang terjadi pada perusahaan LQ 45 pada Rabu, 05 Desember 2018/06:49 WIB. Analis Phintacro Sekuritas Valdy Kurniawan sependapat, faktor fundamental menjadi pengerek harga sahamsaham LQ45 yang sukses mencetak return positif tahun ini. Dia merinci, delapan emiten berhasil membukukan pertumbuhan laba bersih per triwulan III-2018. Sedangkan, dua emiten lainnya, yaitu INCO dan Aneka Tambang ( $\underline{\text { ANTM}})$, berhasil membalik kerugian menjadi laba bersih pada kuartal III2018. Kontan.Co.Id - Jakarta.

Fenomena lain yang terjadi pada Perusahaan LQ 45 sebagian besar Harga saham mengalami penurunan . Perdagangan di Bursa Efek Indonesia (BEI) cukup fluktuatif pada pekan pertama Mei 2019, dari 45 saham anggota indeks LQ45, 30 saham di antaranya membukukan hasil negatif selama periode tersebut. Robotorial /beritagar.id Pada senin 05, Agustus 2019 Kinerja Keuangan Emiten melambat.( www.alinea.id).

Pada tanggal 25 juli 2019, beberapa Emiten didepak dari Indeks LQ 45.(kontan.co.id). Pada tanggal 08 November 2019, Harga saham LQ 45 berguguran (cnbcindonesia.com). Sepanjang Tahun 2019, hingga penutupan bursa hari Jumat (13/12/2019) kinerja indeks LQ45 yang terdiri dari 45 saham yang memiliki likuiditas tinggi disertai kapitalisasi pasar yang cukup besar tersebut mampu menguat 1,52\%, unggul dari Indeks Harga Saham Gabungan (IHSG) yang hanya tumbuh 0,05\%. Market - Yazid Muamar, Cnbc Indonesia

Pasar modal (capital market) merupakan pasar untuk berbagai instrumen keuangan jangka panjang yang bisa diperjual belikan, baik surat utang (obligasi), ekuiti (saham), reksa dana, instrumen derivatif maupun instrumen lainnya. Pasar modal mempunyai fungsi sebagai fungsi ekonomi dan fungsi keuangan dimana fungsi ekonomi ini pasar modal menyediakan fasilitas yang mempertemukan dua kepentingan yaitu pihak yang memiliki kelebihan dana dan pihak yang memerlukan dana sedangkan fungsi keuangan ini pasar modal memberikan kemungkinan dan kesempatan memperoleh 


\section{Maria Verensiana Uhus, Pengaruh Laba Akuntansi, Arus Kas Operasi, Return On Equity, Dan Return \\ On Asset Terhadap Return Saham}

return atau capital gain bagi investor (Halim 2015). Untuk memperoleh data terkait pasar modal, kita membutuhkan laporan keuangan.

PSAK nomor 1 (2013), laporan keuangan adalah suatu penyajian terstruktur dari posisi keuangan dan kinerja suatu entitas. Laporan keuangan bertujuan memberikan informasi tentang posisi keuangan, kinerja dan arus kas perusahaan yang bermanfaat bagi sebagian besar kalangan pengguna laporan dalam rangka membuat keputusan-keputusan ekonomi. Investor menggunakan informasi laporan keuangan untuk menilai harga saham, melakukan keputusan untuk membeli atau menjual investasi di sebuah entitas dan memprediksi return yang akan di kembalikan di kemudian hari.

Fahmi (2015) berpendapat bahwa return merupakan keuntungan yang diharapkan oleh seorang investor dikemudian hari terhadap sejumlah dana yang telah ditempatkan. Return saham juga menunjukkan nilai suatu perusahaan. Nilai saham merupakan indeks yang tepat untuk efektifitas perusahaan. Sehingga sering kali dikatakan memaksimumkan nilai perusahaan juga berarti memaksimumkan kekayaan pemegang saham.

\section{TINJAUAN PUSTAKA}

\section{Investasi}

Investasi adalah penanaman modal untuk satu atau lebih aktiva yang dimiliki dan biasanya berjangka waktu lama dengan harapan mendapatkan keuntungan di masa-msa yang akan datang. Tandelilin (2010), Investasi adalah sebuah komitmen untuk menanamkan sejumlah dana pada saat ini dengan tujuan memperoleh keuntungan dimasa datang. Berdasarkan Pengertian investasi menurut para ahli diatas dapat dinyatakan investasi adalah suatu pengorbanan kekayaan hari ini untuk memperoleh keuntungan dimasa datang.

\section{Saham}

Saham merupakan salah satu instrument pasar modal yang paling banyak diminati oleh investor. Karena mampu memberikan pengembalian yang cukup besar. Saham adalah kertas yang tercantum dengan jelas nilai nominal, nama perusahaan dan diikuti dengan hak dan kewajiban yang telah dijelaskan kepada setiap pemegangnya. Darmadji (2012) saham (stock) merupakan tanda penyertaan atau pemilikan seseorang atau badan dalam suatu perusahaan atau perseroan terbatas. Saham berwujud selembar kertas yang menerangkan bahwa pemilik kertas tersebut adalah pemilik perusahaan yang menerbitkan surat berharga tersebut. 


\section{Maria Verensiana Uhus, Pengaruh Laba Akuntansi, Arus Kas Operasi, Return On Equity, Dan Return}

On Asset Terhadap Return Saham

\section{Return}

Return adalah keuntungan yang diharapkan oleh semua investor dimasa yang akan datang terhadap sejumlah dana yang telah diinvestasi Fahmi, (2015). Menurut Saputra dan Ida, (2016). Laba akuntansi merupakan parameter utama yang menjadi perhatian investor sebelum melakukan investasi. Menurut Aisah (2016) Arus kas operasi merupakan elemen yang penting yang di perlukan investor dalam mengambil keputusan investasi. Menurut Nikmatullah, (2017). Return on equity (ROE) menggambarkan kemampuan perusahaan dalam memberikan keuntungan bagi pemegang saham yang telah menanamkan modalnya pada perusahaan tersebut. ROA merupakan suatu indikator keuangan yang menggambarkan kemampuan perusahaan dalam menghasilkan laba atas total asset yang dimiliki perusahaan.

Penelitian ini menggunakan 5 variabel yaitu LAK, AKO, ROE dan ROA Manfaat adanya kerangka konseptual penelitian untuk mengetahui apakah variabel independen berpengaruh terhadap variabel dependen secara simultan maupun parsial. Mengetahui hubungan variabel deng an hipotesis yang dibuat peneliti sebagai berikut :

\section{Hipotesis Penelitian}

H1 : Laba akuntansi, arus kas operasi, return on equity (roe) dan return on asset (roa) berpengaruh terhadap return saham

H2 : Laba akuntansi berpengaruh terhadap return saham

H3 : Arus kas operasi berpengaruh terhadap return saham

$\mathrm{H} 4$ : Return on Equity (ROE) berpengaruh terhadap return saham

H5 : Return on Asset (ROA) berpengaruh terhadap return saham

\section{METODE PENELITIAN}

Populasi dalam penelitian ini adalah LQ 45 Tahun 2016-2018. Adapun kriteria yang digunakan untuk memilih sampel penelitian ini adalah sebagai berikut :

1. Perusahaan LQ 45 yang terdaftar di bursa efek indonesia periode 2016-2018.

2. Perusahaan LQ 45 yang tidak tetap pada periode 2016-2018

3. Perusahaan LQ 45 yang tidak mempublikasi laporan keuangan periode 2016-2018

4. Perusahaan LQ 45 yang tidak memperoleh Laba periode 2016-2018 
Definisi Operasional Variabel

Tabel 1 Variabel dan definisi operasional

\begin{tabular}{|c|c|c|c|c|}
\hline No & Variabel & Definisi variable & Simbol & Rumus \\
\hline 1. & $\begin{array}{l}\text { Laba } \\
\text { Akuntansi } \\
\text { (LA) }\end{array}$ & $\begin{array}{l}\text { Laba Akuntansi yang } \\
\text { digunakan dalam penelitian } \\
\text { ini dihitung sebagai } \\
\text { "perubahan laba akuntansi" } \\
\text { yaitu selisih antara Laba } \\
\text { Akuntansi yang diperoleh } \\
\text { periode sekarang (t) } \\
\text { dikurangi Laba Akuntansi } \\
\text { yang diperoleh periode } \\
\text { sebelumnya (t-1), dibagi } \\
\text { dengan Laba Akuntansi yang } \\
\text { diperoleh } \\
\text { sebelumnya (t-1). Rumusnya } \\
\text { ditunjukkan sebagai berikut: } \\
\text { (dwi,2012) }\end{array}$ & $\mathrm{LA}(\mathrm{X} 1)$ & $\begin{array}{l}\mathrm{LAK}= \\
\frac{l A K(t)-L A K(t-1)}{L A K(t-1)}\end{array}$ \\
\hline 2. & $\begin{array}{l}\text { Arus Kas } \\
\text { Operasi (AKO) }\end{array}$ & $\begin{array}{l}\text { Dalam penelitian ini Arus Kas } \\
\text { Operasi dihitung sebagai } \\
\text { "perubahan Arus Kas } \\
\text { Operasi” yaitu selisih antara } \\
\text { kas yang diperoleh dari } \\
\text { (digunakan untuk) kegiatan } \\
\text { operasional periode sekarang } \\
\text { (t) dikurangi kas yang } \\
\text { diperoleh dari (digunakan } \\
\text { untuk) kegiatan operasional } \\
\text { periode sebelumnya (t-1), } \\
\text { dibagi dengan kas yang } \\
\text { diperoleh dari (digunakan }\end{array}$ & $\begin{array}{l}\mathrm{AKO} \\
(\mathrm{X} 2)\end{array}$ & $\begin{array}{l}\mathrm{AKO}= \\
\frac{A K O(t)-A K O(t-1)}{A K O(t-1)}\end{array}$ \\
\hline
\end{tabular}




\begin{tabular}{|c|c|c|c|c|}
\hline No & Variabel & Definisi variable & Simbol & Rumus \\
\hline & & $\begin{array}{l}\text { untuk) kegiatan operasional } \\
\text { periode sebelumnya (t-1), } \\
\text { yang rumusnya ditunjukkan } \\
\text { sebagai berikut: (Kartikahadi, } \\
2012 \text { ) }\end{array}$ & & \\
\hline 3. & $\begin{array}{l}\text { Return on } \\
\text { equity (ROE) }\end{array}$ & $\begin{array}{l}\text { Return on equity (ROE) } \\
\text { merupakan perbandingan } \\
\text { antara laba bersih sesudah } \\
\text { pajak dan total ekuitas. Return } \\
\text { on equity (ROE) di sebut juga } \\
\text { dengan imbalan ats ekuitas. } \\
\text { rasio ini mengkaji sejauh } \\
\text { mana suatu perusahaan } \\
\text { menggunakan sumber daya } \\
\text { yang dimiliki agar mampu } \\
\text { memberikan laba atas ekuitas }\end{array}$ & $\begin{array}{l}\text { ROE } \\
(\mathrm{X} 3)\end{array}$ & $\begin{array}{l}\mathrm{ROE}= \\
\text { Laba bersih setelah Paj } \\
\text { Ekuitas Pemegang Saha }\end{array}$ \\
\hline 4. & $\begin{array}{l}\text { Return on asset } \\
(R O A)\end{array}$ & $\begin{array}{l}\text { Rasio yang dapat melihat } \\
\text { sejauh mana investasi yang } \\
\text { telah ditanamkan mampu } \\
\text { memberikan pengembalian } \\
\text { keuntungan sesuai dengan } \\
\text { yang diharapkan dan } \\
\text { investasi tersebut sebenarnya } \\
\text { sama dengan aset perusahaan } \\
\text { yang ditanamkan atau } \\
\text { ditempatkan. }\end{array}$ & $\begin{array}{l}\text { ROA } \\
(X 4)\end{array}$ & ROA $=\frac{\text { Laba Bersih }}{\text { Total Asset }}$ \\
\hline
\end{tabular}




\begin{tabular}{|l|l|l|l|l|}
\hline No & Variabel & Definisi variable & Simbol & Rumus \\
\hline 5. & Return saham & $\begin{array}{l}\text { Return merupakan tingkat } \\
\text { keuntungan yang dinikmati } \\
\text { pemodal atas investasi yang } \\
\text { dilakukannya. Jenis return } \\
\text { yang digunakan dalam } \\
\text { penelitian ini adalah return } \\
\text { realisasi atau sering disebut } \\
\text { actual return yang merupakan } \\
\text { capital gains yaitu selisih } \\
\text { antara harga saham periode } \\
\text { saat ini dengan harga saham } \\
\text { pada periode sebelumnya } \\
\text { dibagi dengan harga saham } \\
\text { periode sebelumnya. Actual } \\
\text { return masing-masing saham } \\
\text { selama periode peristiwa } \\
\text { dirumuskan sebagai berikut : } \\
\text { Menurut Jogiyanto (2014) }\end{array}$ & $\frac{(\text { Pit-Pit-1) }}{(\text { Pit-1) }}$ \\
& & \\
& & \\
& & \\
& & \\
\end{tabular}

\section{HASIL PENELITIAN}

\section{Hasil Uji Asumsi Klasik}

\section{Hasil Uji Normalitas}

Penelitian ini uji normalitas menggunakan pendekatan Kolmogorov-Smirnov dengan dasar pengambilan keputusannya jika nilai Asymp-Sig lebih besar dari 0,05 maka data tersebut berdistribusi normal. Sebaliknya jika nilai Asymp-Sig kurang dari 0,05 maka data tersebut tidak berdistribusi normal. Hasil uji normalitas dapat di lihat pada Tabel 4.6 Berikut ini. 
Tabel 2 Hasil Uji Normalitas

\begin{tabular}{|ll|l|}
\hline & & $\begin{array}{l}\text { Unstandardized } \\
\text { Residual }\end{array}$ \\
\hline N & & 33 \\
Normal Parametersa,b & Mean &, 0000000 \\
& Std. Deviation &, 19977081 \\
Most Extreme Differences & Absolute &, 103 \\
& Positive &, 069 \\
& Negative &,- 103 \\
Test Statistic & &, 103 \\
Asymp. Sig. (2-tailed) & & \\
& &, $200 \mathrm{c,d}$ \\
\hline
\end{tabular}

a. Test distribution is Normal.

b. Calculated from data.

c. Lilliefors Significance Correction.

$\mathrm{d}$. This is a lower bound of the true significance.

Berdasarkan Tabel 2 dapat dilihat bahwa nilai Asymp.sig setiap variabel berada atau lebih besar dari 0,05 maka dapat disimpulkan bahwa data dalam penelitian ini berdistribusi normal.

\section{Uji Multikolinieritas}

Untuk mengetahui ada tidaknya multikolinieritas adalah dengan melihat nilai VIF (Variance Inflation Factor) jika nilainya $<10$ berarti tidak terjadi multikolinieritas.. Hasil uji multikolinieritas dapat dilihat pada tabel 3 berikut.

Tabel 3 Hasil Uji Multikolinieritas

\begin{tabular}{|l|l|l|l|}
\hline \multirow{2}{*}{ Variabel } & \multicolumn{2}{|l|}{ Collinearity statistics } & \multirow{2}{*}{ Keterangan } \\
\cline { 2 - 3 } & Tolerance & VIF & \\
\hline LAK $(X 1$ & 0,731 & 1,368 & Tidak terjadi Multikolinieritas \\
\hline AKO $(X 2)$ & 0,753 & 1,328 & Tidak terjadi Multikolinieritas \\
\hline ROE $(X 3)$ & 0,305 & 3,282 & Tidak terjadi Multikolinieritas \\
\hline
\end{tabular}




\begin{tabular}{|l|l|l|l|}
\hline ROA (X4) & 0,311 & 3,218 & Tidak terjadi Multikolinieritas \\
\hline
\end{tabular}

a. Dependent Variable: RETURN SAHAM sumber: data sekunder diolah peneliti tahun 2020

Tabel diatas menunjukan bahwa nilai VIF setiap variabel lebih kecil dari 10. Ini berarti tidak di temukan korelasi antar variabel bebas atau tidak terjadi Multikolinieritas.

\section{Hasil Uji Autokorelasi}

Tabel 4 Hasil uji Asumsi Autokorelasi

\begin{tabular}{|l|l|l|l|}
\hline DU & $N$ & $K$ & $D W$ \\
\hline 1,73 & 33 & 11 & 1,962 \\
\hline
\end{tabular}

Sumber : data sekunder diolah oleh peneliti tahun 2020

Tabel diatas menunjukan nilai durbin Watson 1,962. Karena nilai durbin Watson lebih kecil dari nilai Du 1,73. Dan lebih kecil dari 4-DU. Maka dapat dinyatakan bahwa model regresi bebas dari gejala autokorelasi.

\section{Uji Heteroskedastisitas}

Untuk mengetahui ada tidaknya heteroskedastisitas dilakukan dengan metode scatterplot. Jika grafik scatterplot menunjukan tidak beraturan maka dinyatakan tidak terjadi heteroskedastisitas. Hasil uji heteroskedastisitas disajikan pada gambar 1 berikut.

\section{Gambar 1 Hasil Uji Heteroskedastisitas}

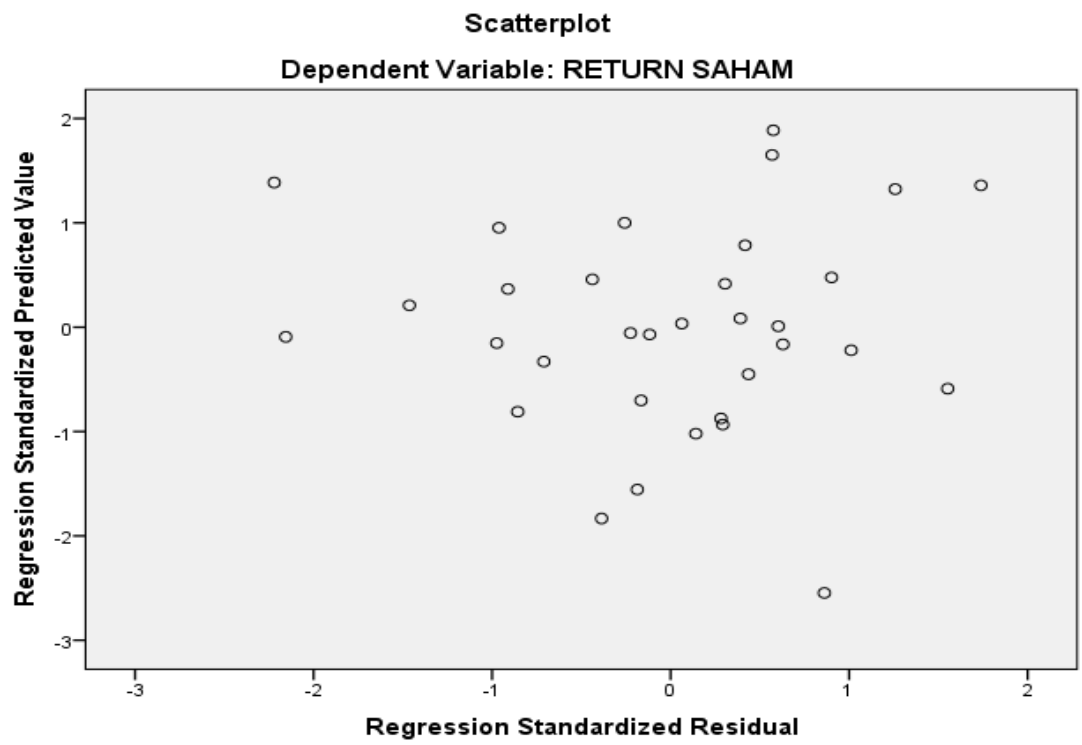




\section{Maria Verensiana Uhus, Pengaruh Laba Akuntansi, Arus Kas Operasi, Return On Equity, Dan Return On Asset Terhadap Return Saham}

Gambar di atas menunjukan bahwa scatterplot tidak beraturan atau tidak membentuk suatu pola tertentu maka dapat dinyatakan bahwa tidak terjadi gejala heterokedastisitas dalam model regresi.

\section{Hasil Uji Analisis Regresi Berganda}

Analisis yang digunakan untuk menguji hipotesis dalam penelitian ini menggunakan analisis linear berganda . regresi linear berganda digunakan untuk mengetahui pengaruh variabel independen terhadap variabel dependen. Hasil analisis regresi linear berganda di sajikan pada tabel 5 berikut.

Tabel 5 Hasil Analisis Regresi Berganda

\begin{tabular}{|ll|l|l|l|l|}
\hline \multirow{2}{*}{ Model } & \multicolumn{2}{|l|}{ Unstandardized Coefficients } & & \multirow{2}{*}{ Sig. } \\
\cline { 3 - 4 } & B & B Std. Error & T &, 199 \\
& LAK &, 474 &, 068 & 1,315 &, 012 \\
& AKO &, 244 &, 112 & 2,704 &, 038 \\
& ROE &,- 197 &, 441 &,- 447 &, 658 \\
& ROE &,- 465 &, 709 &,- 656 &, 517 \\
\hline
\end{tabular}

a. Dependent Variable: RETURN SAHAM

Sumber: Data sekunder, diolah peneliti, 2020

Dari tabel diatas maka persamaan regresi sebagai berikut :

$\mathrm{Y}=\mathrm{a}+\mathrm{b}_{1} \mathrm{X}_{1}+\mathrm{b}_{2} \mathrm{X}_{2}+\mathrm{b}_{4} \mathrm{X}_{4}$

$Y=0,089+-0,474 X_{1}+0,244 X_{2}+-0,197 X_{3}+-0,465 X_{4}$

Dari persamaan regresi tersebut, diketahui bahwa :

a. Koefisien regresi variabel laba akuntansi bernilai positif sebesar 0,474. ini menunjukan bahwa apabila laba akuntansi meningkat 1 persen maka Return saham akan meningkat sebesar 0,474 atau sebesar $47,4 \%$ Persen.

b. Koefisisien regresi variebel arus kas operasi bernlai posistif sebesar 0,244 Ini menunjukan bahwa apabila arus kas operasi meningkat 1 persen maka Return saham akan meningkat sebesar 0.244 atau $24,4 \%$ Persen.

c. Koefisien regresi return on equity bernilai Negative sebesar -0,197.ini menunjukan bahwa apabila return on equity menurun 1 persen maka Return saham akan menurun sebesar -0,197 atau -19,7 Persen. 
d. Koefisien regresi return on asset bernilai Negative sebesar -0,465. Ini menunjukan bahwa return on asset menurun1 persen maka Return saham akan menurun sebesar -0,465 atau - 46,5Persen.

\section{Pengujian Hipotesis}

\section{Hasil Uji Pengaruh Simultan (Uji F)}

Uji F-test digunakan untuk membuktikan apakah variable X1,X2,X3 dan X4 secara bersamasama mempengaruhi Y. Rekapitulasi hasil Uji F dapat dilihat pada tabel sebagai berikut.

Tabel 6 Uji F-test

\begin{tabular}{|ll|l|l|l|l|l|}
\hline \multicolumn{2}{|l|}{ Model } & $\begin{array}{l}\text { Sum } \\
\text { Squares }\end{array}$ & Df & Mean Square & F & Sig. \\
\hline 1 & Regression & 1,351 & 4 &, 338 & 7,406 &, $000^{\mathrm{b}}$ \\
& Residual & 1,277 & 28 &, 046 & & \\
& Total & 2,628 & 32 & & & \\
\hline
\end{tabular}

a. Dependent Variable: RETURN SAHAM

b. Predictors: (Constant), ROE, AKO, LABA AKUNTANSI, ROE

Tabel 6 menunjukan bahwa nilai signifikansi uji simultan atau uji F sebesar 0,000<0,05. Jika dilihat dari hasil di atas maka dapat disimpulkan secara simultan variabel laba akuntansi,arus kas operasi, return on equity dan return on asset berpengaruh terhadap Return saham. hal ini menunjukan bahwa model yang digunakan layak untuk diterima.

\section{Hasil Uji Pengaruh Parsial (Uji t)}

Uji t digunakan untuk mengetahui pengaruh variabel bebas terhadap variabel terikat secara individual. Hipotesis yang diuji dengan menggunakan uji t adalah laba akuntansi, arus kas operasi, Return on equity dan Return on asset. menguji koefisien regresi secara parsial.hasil uji t terlihat pada tabel :

Tabel 7 Hasil uji t (parsial)

\begin{tabular}{|l|l|l|}
\hline \multicolumn{1}{|c|}{ Variabel } & T hitung & Signifikan \\
\hline Laba Akuntansi & 2,704 & 0,012 \\
\hline Arus kas operasi & 2,173 & 0,038 \\
\hline Return on equity & $-0,447$ & 0,658 \\
\hline Return on asset & $-0,656$ & 0,517 \\
\hline
\end{tabular}

Sumber: data diolah peneliti,2020 


\section{Maria Verensiana Uhus, Pengaruh Laba Akuntansi, Arus Kas Operasi, Return On Equity, Dan Return \\ On Asset Terhadap Return Saham}

Uji hipotesis dalam penelitian ini mengunakan uji t. uji t digunakan untuk menguji signifikan pengaruh variabel independen secara parsial terhadap variabel dependen dengan menganggap variabel lain bersifat konstan. Dari hasil analisis regresi linear berganda pada tabel diatas terlihat bahwa:

\section{Hasil Uji hipotesis Kedua}

Berdasarkan hasil analisis yang di peroleh nilai signifikan sebesar $0.012<0,05$ dengan nilai T hitung 2,704 ini menunjukan bahwa variabel laba akuntansi berpengaruh terhadap return saham, atau Ha di Terima Ho di Tolak.

\section{Hasil uji hipotesis ketiga}

Berdasarkan hasil analisis yang di peroleh nilai signifikan sebesar $0.038<0,05$ dengan nilai $\mathrm{T}$ hitung 2,173 ini menunjukan bahwa variabel laba akuntansi berpengaruh terhadap return saham, atau Ha di Terima Ho di Tolak.

\section{Hasil uji hipotesis ke empat}

Berdasarkan hasil analisis yang di peroleh nilai signifikan sebesar $0.658>0,05$ dengan nilai $\mathrm{T}$ hitung -0,447 ini menunjukan bahwa variabel return on equity tidak berpengaruh terhadap return saham, atau ha di tolak ho di terima.

\section{Hasil uji hipotesis ke lima}

Berdasarkan hasil analisis yang di peroleh nilai signifikan sebesar $0.517>0,05$ dengan nilai $\mathrm{T}$ hitung -0,656 ini menunjukan bahwa variabel return on asset tidak berpengaruh terhadap return saham, atau ha di terima ho di tolak.

Uji koefisien Determinasi ( $\left.\mathbf{R}^{2}\right)$

Tabel 8 koefisien Determinasi $\left(\mathbf{R}^{2}\right)$

\begin{tabular}{|l|l|lc|}
\hline Model & \multicolumn{1}{|c|}{$\mathrm{R}$} & & R Square \\
\hline 1 &, $717^{\mathrm{a}}$ &, 514 \\
\hline
\end{tabular}

a. Predictors: (Constant), ROE, AKO, LABA AKUNTANSI, ROE

b. Dependent Variable: RETURN SAHAM

Koefisien determinasi pada intinya mengukur seberapa jauh kemampuan model dalam menerangkan variasi variabel dependen. Nilai Rsquer sebesar 0,514 menunjukan bahwa perubahan naik tururnnys return saham di pengaruhi oleh LAK, AKO, ROE, dan ROA sebesar 51,4\%. Sisanya $48,6 \%$ di pengaruhi oleh variabel lain yang tidak diteliti dalam penelitian ini.

Hasil uji koefisien determinasi, pada (Adjusted $R^{2}$ ), terlihat bahwa nilai Adjusted $R^{2}$ adalah 0,514 artinya $51,4 \%$. Ini menunjukkan bahwa variabel independen atau bebas yaitu laba akuntansi,arus kas 


\section{Maria Verensiana Uhus, Pengaruh Laba Akuntansi, Arus Kas Operasi, Return On Equity, Dan Return}

On Asset Terhadap Return Saham

operasi,return on equity dan return on asset dapat menjelaskan variasi variabel dependen yaitu return saham dan sisanya dijelaskan oleh variabel independen lain, yang tidak dijelaskan pada penelitian ini. Artinya return saham memiliki banyak faktor variabel yang dapat memengaruhi dan banyak faktor tersebut tidak dijelaskan dalam penelitian ini.

\section{PEMBAHASAN}

\section{Pengaruh Laba Akuntansi, Arus Kas Operasi, Return On Equity Dan Return}

\section{On Asset Terhadap Return Saham}

Hipotesis pertama menyatakan bahwa LAK, AKO, ROE dan ROA berpengaruh terhadap RS. Hasil analisis ini menunjukan bahwa kenaikan atau penurunanan dari LAK, AKO, ROE dan ROA maka akan mempengaruhi RS pada perusahaan LQ 45. Artinya, Hasil ini mengindikasikan bahwa seluruh variabel independen mempunyai kemampuan dalam mempengaruhi $R S$ secara bersama sama disebabkan karena investor beranggapan bahwa informasi dalam laporan keuangan, khususnya informasi dalam laporan $\mathrm{LAK}, \mathrm{AKO}, \mathrm{ROE}$ dan $R O A$ pada perusahaan LQ 45 mempunyai peran dalam pengambilan keputusan investasi.

LAK berpengaruh secara simultan terhadap Return saham disebabkan LAK dipakai untuk mengetahui bagaimana perkembangan kedepan suatu perusahaan dan LAK dapat mengetahui bagaimana kinerja manajemen yang di gambarkan sebagai selisih antara pendapatan dan beban, karenanya laba akuntansi selalu menjadi perhatian paling utama bagi setiap para investor (Saputra dan Ida, 2016). AKO dapat berpengaruh terhadap Return saham. Menunjukan arus kas operasi merupakan elemen utama yang paling penting bagi investor setiap mengambil keputusan investasi. Return on equity (ROE) menggambarkan kemampuan perusahaan dalam memberikan keuntungan bagi pemegang saham yang telah menanamkan modalnya pada perusahaan tersebut. Menurut Fakhruddin, (2018). ROA merupakan suatu indikator keuangan yang menggambarkan kemampuan perusahaan dalam menghasilkan laba atas total asset yang dimiliki perusahaan.

Penelitian diatas didukung oleh linda dkk.(2018), Nasikah (2017), Anwar (2018), yaitu LAK, $A K O, R O E$ dan ROA mempunyai pengaruh secara simultan terhadap $R S$. Kesimpulan dari hasil analisis yang dilakukan dapat diketahui bahwa LAK, AKO, ROE dan ROA mempunyai pengaruh secara simultan terhadap $R S$.

\section{Pengaruh Laba Akuntansi Terhadap Return Saham}

Hipotesis kedua menyatakan laba akuntansi berpengaruh signifikan terhadap return saham. Hal ini dapat dilihat dari hasil Uji t pada bab sebelumnya. ini menunjukan bahwa informasi laba 


\section{Maria Verensiana Uhus, Pengaruh Laba Akuntansi, Arus Kas Operasi, Return On Equity, Dan Return \\ On Asset Terhadap Return Saham}

memberikan reaksi yang positif kepada mereka yang melakukan investasi pada perusahaan LQ 45. Hal ini dapat membawa dampak yang baik bagi perusahaan tersebut. Dampak yang terjadi jika laba akuntansi mengalami kenaikan atau stabil akan mempengaruhi investor dan otomatis dapat meningkatkan minat investor untuk melakukan investasi.

Hasil Peneliti didukung dengan teori yang menyatakan bahwa laba akuntansi merupakan parameter utama yang menjadi perhatian investor sebelum melakukan investasi. Semakin tinggi laba akuntansi suatu perusahaan maka kemampuan perusahaan dalam membagi dividen juga semakin tinggi otomatis ini punya pengaruh kepada $R S$. jika LAK meningkat maka harga saham juga akan semakin tinggi dan return yang diperoleh perusahaan juga akan meningkat Saputra dan Ida (2016). Gilbert (2016), Nasikah 2017, Linda dkk 2018, menyatakan LAK mempunyai pengaruh terhadap RS Namun bertolak dengan penelitian Khairunnisa, 2016: yaitu LAK tidak dapat pengaruh terhadap RS

\section{Pengaruh Arus Kas Operasi Terhadap Return Saham}

Hipotesis ketiga yang menyatakan bahwa Arus kas operasi berpengaruh signifikan terhadap return saham. hal ini dapat dilihat dari uji t bab sebelumnya. Artinya arus kas operasi adalah salah satu informasi yang ada dalam laporan keuangan dan diperhatikan oleh seorang investor dan calon investor sebelum melakukan investasi. Arus kas operasi bernilai positif akan mencerminkan keberhasilan suatu perusahaan dalam mengelola operasi bisnis utamanya, dan hal inipun akan berpengaruh terhadap return saham yang akan diterima oleh seorang investor. Jika arus kas operasi pada perusahaan LQ 45 stabil akan menyebabkan kemampuan perusahaan dalam menghasilkan kas dari kegiatan operasi normal dan perusahaan dapat dikatakan baik hal ini menyebabkan Minat investor untuk melakukan investasi pada perusahaan tersebutmeningkat.

Hal ini di dukung dengan teori yang menyatakan bahwa Arus kas operasi merupakan elemen yang penting yang di perlukan investor dalam mengambil keputusan investasi. Apabila Semakin tingi arus kas operasi maka kemampuan perusahaan dalam menghasilkan kas dari kegiatan operasi normal perusahaan dapat dikatakan baik. Hasil penelitian ini sejalan dengan penelitian yang dilakukan oleh Nurchayati dkk 2017, haris dkk, 2018 dan khairunisa,2016 yang menyatakan bahwa arus kas operasi berpengaruh terhadap Return saham. namun bertolak belakang dengan hasil penelitian yang dilakukan oleh rizal dan selvia, 2016 yang mengatakan bahwa arus kas operasi tidak berpengaruh terhadap return saham.

Kesimpulan dari hasil analisis yang dilakukan dapat diketahui bahwa a Jika arus kas operasi pada suatu perusahaan stabil akan menyebabkan kemampuan perusahaan dalam menghasilkan kas 


\section{Maria Verensiana Uhus, Pengaruh Laba Akuntansi, Arus Kas Operasi, Return On Equity, Dan Return}

On Asset Terhadap Return Saham

dari kegiatan operasi normal dan perusahaan dapat dikatakan baik . hal ini menyebabkan Minat investor untuk melakukan investasi pada perusahaan tersebut meningkat.

\section{Pengaruh ROE Terhadap RS}

Hipotesis keempat menyatakan bahwa Return On Equity tidak berpengaruh terhadap return saham Hal tersebut dapat dilihat dari uji t pada bab sebelumnya. Disini menunjukan bahwa hasil ratarata pertahun pada perusahaan LQ 45 menyebabkan perputaran pada Return On Equity tidak stabil. Ini akan membawa dampak yang kurang baik bagi investor karena investor akan melakukan investasi pada suatu perusahaan jika Return On Equity meningkat. Tetapi yangterjadi pada perusahan LQ 45 perputaran Return On Equity tidak stabil menyebabkan minat investor untuk melakukan investasi berkurang.

Wiagustini (2010) ROE dapat menjadi besar oleh karena labanya meningkat atau modalnya Modal menurun pada suatu perusahaan memungkinkan untuk perusahaan tersebut berhutang. Namun hasil penelitian menunjukkan bahwa return on equity tidak berpengaruh terhadap return saham berarti tinggi rendahnya return on equity tidak akan mempengaruhi investor dalam pengambilan keputusan investasinya, karena apabila perusahaan mampu mengelola modalnya dengan baik maka akan mampu menghasilkan profit. Maka tidak semua perusahaan yang modalnya menurun akan berpengaruh pada return saham perusahaan tersebut.

Hasil tersebut di dukung oleh Pandu (2016) menyatkan bahwa ROE Secara parsial tidak memiliki pengaruh signifikan terhadap $R S$, mengatakan bahwa setiap perubahan pada nilai ROE tidak mengakibatkan perubahan secara signifikan pada nilai RS. Return On Equity merupakan rasio yang menunjukkan kemampuan perusahaan dalam menghasilkan laba dari modal sendiri dan hal ini terjadi karena modal yang digunakan tidak mampu memberikan keuntungan yang besar bagi perusahaan, artinya pengelolaan dana modal dapat dikatakan tidak efisien, karena dana ekuitas yang besar tidak diikuti dengan keuntungan yang besar.

\section{Pengaruh ROA Terhadap RS}

Hipotesis kelima menyatakan bahwa $R O A$ tidak mempunyai pengaruh terhadap $R S$. Hal tersebut dapat dilihat dari uji t pada bab sebelumnya. Disini menunjukan bahwa hasil rata-rata pertahun pada perusahaan LQ 45 yang menyebabkan perputaran asset tidak menghasilkan laba yang stabil dan Ini akan berdampak kurang baik bagi perusahaan maupun investor.

Hasil penelitian ini sejalan dengan penelitian yang dilakukan oleh Ningsih, dkk (2018) yang menyatakan bahwa Return On Asset tidak mempunyai pengaruh terhadap RS. Hasil penelitian ini membuktikan bahwa suatu perusahaan yang tidak memperoleh laba dan mengalami penurunan 


\section{Maria Verensiana Uhus, Pengaruh Laba Akuntansi, Arus Kas Operasi, Return On Equity, Dan Return \\ On Asset Terhadap Return Saham}

membuat investor kurang tertarik untuk menanamkan (investasi) dananya pada perusaaan tersebut, maka return saham menurun. Namun bertentangan dengan penelitian ningsih dkk 2018 yang menyatakan bahwa ROA mempunyai pengaruh terhadap RS tetapi bertentangan juga dengan Vera dkk (2015) yang menyatakan bahwa Return On Asset tidak berpengaruh signifikan terhadap return saham. Tidak signifikannya return on assets terhadap return saham menunjukkan bahwa investor tidak terlalu memperhatikan return on assets dalam keputusannya berinvestasi. ROA memiliki kelemahan yaitu cenderung berfokus pada tujuan jangka pendek dan bukan tujuan jangka panjang. ROA tidak menunjukkan prospek ke depan atas perusahaan sehingga investor tidak dapat meramalkan keuntungan yang akan diperoleh di masa depan. Namun penelitian ini bertolak belakang dengan penelitian yang dilakukan oleh Lokorda dan Heny (2016) yang menyatakan Return On Asset berpengaruh signifikan terhadap return saham.

\section{KESIMPULAN}

Penelitian ini bertujuan untuk mengetahui pengaruh laba akuntansi, arus kas operasi, return on equity (ROE), return on asset (ROA) terhadap return saham. Berdasarkan pengujian dan penjelasan di simpulkan bahwa secara simultan Laba akuntansi, arus kas operasi, return on equity (ROE), return on asset (ROA) berpengaruh terhadap return saham perusahaan LQ 45. Hal ini menunjukan bahwa informasi laba akuntansi, arus kas operasi, return on equity (ROE), return on asset (ROA) merupakan informasi yang diperlukan oleh investor dalam mengambil keputusan sebelum melakukan investasi. Sedangkan Laba akuntansi, Arus kas operasi secara berpengaruh dan signifikan terhadap return saham perusahaan LQ 45 yang terdaftar di BEI periode 2016-2018. Dan Return on equity (ROE), Return on asset (ROA) secara parsial tidak berpengaruh terhadap return saham perusahaan LQ 45 yang terdaftar di BEI periode 2016-2018.

\section{Daftar Pustaka}

Aisah, A., \& Mandala, K. (2016). Pengaruh Return on Equity, Earning Per Share, Firm Size Dan Operating Cash Flow Terhadap Return Saham. E-Jurnal Manajemen Universitas Udayana, 5(11), 254691.

Anwar, Marryam. (2016) Impact of firms Performance on stock returns evidence From Listed companies of FTSE 100 Index London,UK.Jurnal. The Univers Ity Of Lahore: Pakistan. (Online), (http://globalijournals. org/GJMBR-Volume 16/15- Impact-of-firms-performance.pdf), diakses 11 November 2018.

Dwi, Martani. (2012), Akuntansi keuangan Menengah: Berbasis PSAK. Jakarta:Salemba Empat

Darmadji, T dan Fakrudin. M. H, (2012). Pasar modal di Indonesia. Edisi ketiga. Salemba Empat: Jakarta. Fahmi, Irham. (2015). Manajemen Investasi Edisi 2. Jakarta: Salemba Empat. 


\section{Maria Verensiana Uhus, Pengaruh Laba Akuntansi, Arus Kas Operasi, Return On Equity, Dan Return}

On Asset Terhadap Return Saham

Gilbert dkk (2016). Pengaruh Laba Akuntansi, dan Arus Kas Operasi Terhadap Return Saham Pada Perusahaan Manufaktur SektorIndustri Barang Konsumsi yang Terdaftar Di Bursa Efek Indonesia. Jurnal Emba. Universitas Sam Ratulangi Manado. Vol.5 N0 1. (Online), (https://media.neliti.com/media/publications/128832-ID-pengaruh -laba-akuntansi-dan-arus-kasope.pdf), diakses 11 September 2018.

Halim, Abdul. (2015). Analisis investasi dan di asset keuangan, mitra wacana Media.

Jogiyanto, Hartono. (2014) . Teori Portofolio dan Analisis Investasi. Edisi 8 BPFE:Yogyakarta.

Kartikahadi,dkk. (2012). Akuntansi Keuangan Berdasarkan SAK Berbasis IFRS.Salemba empat.Jakarta

Linda A Razak, dan Rahmi Syafitri. (2018). Laba akuntansi, total arus kas dan Net Profit Margin berpengaruh Terhadap Return Saham pada Perusahaan Otomotif yang terdaftar di Bursa Efek Indonesia Jurnal Akun Nabelo: Jurnal Akuntansi Netral, Akuntabel, Objektif Volume 1/Nomor 1/Juli 2018

Nasikah, Durotin. 2017. Pengaruh leverage, Komponen Arus kas, Laba Akuntansi Terhadap Return saham Di Perusahaan Manufaktur yang terdaftar di bursa efek Indonesia periode 2013-2015. Jurnal. Universitas Nusantara PGRI Kediri. (Online), (http://simki.unpkrdiri.ac.id/mahasiswalfileartikel/2017/bcd635b2ed7cbfbd49cc0feee7d.pdf), diakses 20 Oktober 2018.

Ningsih Hikmawati , Adi Wiratno, Suyanto ,Darmansyah, 2018 Pengaruh Return On Assets, Return On Equity, Debt To Equity Ratio, Inflasi, Dan Suku Bunga Terhadap Return Saham Pada Perusahaan Manufaktur Di Bursa Efek Indonesia (Studi Empiris Pada Perusahaan Secondary Sectors Periode 2010-2015) Jurnal Ilmiah Akuntansi Kesatuan Vol. 6 No. 1, April 2018 pg. 063- 076 STIE Kesatuan ISSN $2337-7852$.

Pandu Dewanthoro. (2016). pengaruh Return On Asset (ROA), Return On Equity (ROE), Earning Per Share (EPS), dan Net Profit Margin (NPM) terhadap Return Saham perusahaan sekotor Properti dan Real Estate di Bursa Efek Indonesia.https://dspace.uii.ac.id/bitstream/handle/123456789/7589/08\%20naskah\%20publikas i.pdf? sequence $=12 \&$ isAllowed $=y$

Saputra, Kurnia Adi dan Ida Bagus Putra Astika. (2016). Pengaruh Informasi Laba Akuntansi dan Informasi Corporate Social And Responsibility Pada Return Saham (Studi Pada Perusahaan Pertambangan Di BEI). Jurnal Akuntansi Universitas Udayana.

Tandelin dkk (2010). Portofolio dan investasi :teori dan aplikasi kanisius: Yogyakarta. 